\title{
Boissé receives ACRL's highest honor
}

Joseph A. Boissé, university librarian at the University of California, Santa Barbara, has been named the 1995 ACRL Academic/Research Librarian of the Year. Boissé will receive the award $(\$ 3,000$ and a citation) at a reception given in his honor from 4:30 to 6:00 p.m. on Monday, June 26, 1995, during the ALA Annual Conference in Chicago. Baker \& Taylor Books sponsors this reception and donates the cash award and citation.

In nominating Boissé, his colleagues said, "His pioneering of bibliographic instruction as an integral part of the

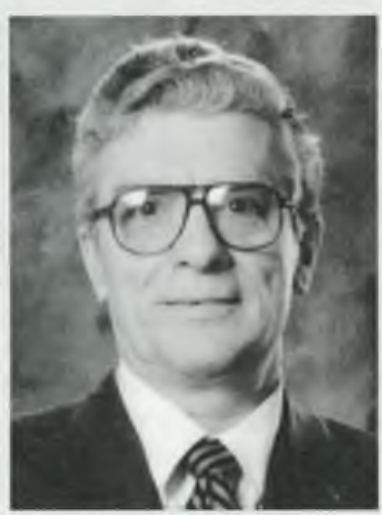

Joseph A. Boissé
Libraries (1971-73), assistant director of the Lawrence University Library (1968-71), and regional librarian and special services coordinator for the Vermont Department of Libraries (1967-68).

He has long been an innovator in many ways. "At the University of Wisconsin-Parkside," said the award committee, "Dr. Boissé was responsible for the creation of a competency-based library user education program which served as a model for the profession for over a decade. At the University of CaliforniaSanta Barbara, Dr. Boissé inimission of an academic library, the leadership role he has played in mentoring minorities in the field of academic librarianship, and his extensive contributions to professional organizations ... place him among the outstanding leaders in our profession."

In selecting Boissé for this honor, the award committee said, "Dr. Boissé has contributed to academic librarianship through his service, publications, and public presentations, and has been responsible for the creation of model library programs in library instruction and library diversity. Within the libraries where he has worked, he is noted for creating a dynamic and supportive environment for staff which has led to an unusually professionally active staff and an outstanding group of alumni who are playing leadership roles in academic libraries." The committee added, "What is particularly impressive, however, about Dr. Boissé's accomplishments is the number of librarians who comment on how he has mentored and coached them. making them better professionals and helping them achieve their career goals."

Boissé's career over the past 27 years has included positions as professor and director of libraries at Temple University (1979-83), director of the library/learning center at the University of Wisconsin-Parkside (1973-79), assistant state librarian and director of extension services at the Vermont Department of tiated a Diversity Residency Program which stimulated the University of California System to initiate a similar system-wide program."

Professionally active, Boissé has served as ACRL president (1988-89), vice-president (1987-88), Salt Lake City National Conference Executive Committee chair (1990-92), and on many committees including the Colleagues Committee (1993-95), Appointments and Nominations (1983-84), and the Continuing Education Committee (1979-80).

As a member of ALA, Boissé has served on the ALA Council (1991-1995), as chair of the Committee on Instruction in Library Use (1979-83), and on many other committees. He has also been active in the Association of Research Libraries, the Center for Research Libraries, the Research Libraries Group, ALA's Library Administration and Management Association, the International Federation of $\mathbf{L i}-$ brary Associations, and the California Library Association, among others.

The Academic/Research Librarian of the Year Award is given annually to recognize an individual who is making an outstanding contribution to academic or research librarianship and library development. Previous winners include: Irene B. Hoadley (1994); William A. Moffett (1993); Carla Stoffle (1992); Richard De Gennaro (1991); Patricia Battin (1990); John P. McGowan (1989); Edward G. Holley (1988); and Duane Webster (1987). 